\title{
'What's in a Name?': Mislabelling, misidentification, and the US government's failure to protect human trafficking survivors in the Central American refugee crisis
}

\author{
Katherine Soltis and Rebecca Walters
}

\section{Abstract}

This article explores how competing and overlapping legal classifications such as 'victim of trafficking', 'smuggled migrant', 'illegal alien', and 'refugee' play out in the United States (US) immigration system. In particular, it focuses on the repeated failure of US authorities to identify and protect survivors of human trafficking who were victimised by the smugglers they voluntarily employed in fleeing their home countries - a scenario that is becoming increasingly common in the midst of the Central American refugee crisis. The article draws upon the authors' experience providing direct legal representation to Central American migrants in the US to discuss how misassumptions about this population, a misunderstanding of the relevant legal terminology, and the US government's focus on border security negatively impact the conduct of law enforcement agencies and immigration adjudicators. Due in large part to the US government's increased restrictions on, and criminalisation of, many forms of migration, survivors of human trafficking who are victimised by smugglers often find themselves classified as 'illegal aliens' or 'criminal aliens', and their legitimate claims for protection are frequently dismissed for the irrelevant fact that they initially consented to be smuggled. Such mistreatment and misidentification fail to hold perpetrators accountable, and to offer assistance to populations that the US government has pledged to defend.

Keywords: refugees, border security, $\mathrm{T}$ nonimmigrant status, human smuggling

Please cite this article as: K Soltis and R Walters, “What's in a Name?": Mislabelling, misidentification, and the US government's failure to protect human trafficking survivors in the Central American refugee crisis', AntiTrafficking Review, issue 11, 2018, pp. 85-102, www.antitraffickingreview.org

This is an open-access article distributed under the terms of the Creative Commons Attribution License (CC-BY). Under the CC-BY license, the public is free to share, adapt, and make commercial use of the work. Users must always give proper attribution to the authors and the Anti-Trafficking Review. 


\section{Introduction}

Under US federal law, the legal definitions and procedural screening mechanisms associated with terms such as 'human trafficking', 'human smuggling', and 'illegal immigration' dramatically affect the immigration remedies available to the individuals concerned, and the public benefits and aid programmes they can access. Furthermore, such terms strongly influence how they are perceived and dealt with by US immigration authorities, including US Customs and Border Protection (CBP), US Citizenship and Immigration Services (USCIS), US Immigration and Customs Enforcement (ICE), and other federal government agencies.

Several publications have explored the theoretical and policy implications of the competing and potentially overlapping legal categories applied to human trafficking survivors in the US. ${ }^{1}$ This article, however, offers a unique perspective by drawing from the authors' personal experiences representing low-income migrants ${ }^{2}$ in the Washington, DC metropolitan region, including hundreds

1 See, e.g., J C Hathaway, 'The Human Rights Quagmire of "Human Trafficking”, Virginia Journal of International Law, vol. 49, no. 1, 2008, pp. 1-59; A Gallagher, 'Human Rights and Human Trafficking: Quagmire or Firm Ground? A response to James Hathaway', Virginia Journal of International Law, vol. 49, no. 4, 2009; J Chacon, 'Tensions and Trade-offs: Protecting trafficking victims in the era of immigration enforcement', University of Pennsylvania Law Review, vol. 158, issue 6, 2010, pp. 1609-1653; J Chacon, 'Misery and Myopia: Understanding the failures of U.S. efforts to stop human trafficking', Fordham Law Review, vol. 74, issue 6, 2006, pp. 2977-3040; J Srikantiah, 'Perfect Victims and Real Survivors: The iconic victim in domestic human trafficking law', Boston University Law Review, vol. 87, 2007.

2 The use of the term migrant in this paper captures 'any person who is moving or has moved across an international border or within a State away from his/her habitual place of residence, regardless of (1) the person's legal status; (2) whether the movement is voluntary or involuntary; (3) what the causes for the movement are; or (4) what the length of the stay is', as defined by the International Organization for Migration. As such, the term is not limited to individuals relocating due to seasonal work or for broader economic reasons only, as is sometimes the connotation in the US context. 
of asylum seekers and human trafficking survivors seeking legal protections since the Central American refugee crisis began. ${ }^{3}$

The Central American refugee crisis is rooted in the Northern Triangle, consisting of El Salvador, Honduras and Guatemala. High crime rates perpetrated by gangs (known as maras), domestic abuse and sexual violence have contributed to the displacement of hundreds of thousands of people, predominantly women and children. ${ }^{4}$ According to the United Nations High Commissioner for Refugees, 'From 2011 to 2016, the number of people from the Northern Triangle who have sought refuge in surrounding countries has increased by 2,249 per cent. $^{5}$ In 2014, the US experienced a surge of unaccompanied minors and family units seeking asylum at the southern border ${ }^{6}$ and the numbers have remained high ever since, with 415,191 apprehensions recorded in $2017 .^{7}$

The desperation of many Central Americans to flee their countries of origin, coupled with the US government's enhanced focus on border control and the criminalisation of many forms of migration, has given smuggling networks substantial power over asylum seekers, and has contributed to the growth of an organised criminal industry rampant with exploitation and abuse. Several

3 Throughout the article, our use of the term 'Central American refugee crisis' refers to the surge of Central American asylum seekers requesting protection in the United States starting in 2014 due to legitimate fears of gang-related violence and persecution. Most of these individuals have not been formally classified as 'refugees', but we use this term here to signify our belief that the vast majority of them do have a legitimate fear of return to their countries of origin.

4 United States of America for the Office of the United Nations High Commissioner for Refugees, Central American Refugee Crisis: Families and unaccompanied children are fleeing horrific gang violence, retrieved 7 January 2018, https://www.unrefugees.org/emergencies/central-america/.

5 Ibid.

6 United States Customs and Border Protection, United States Border Patrol Southwest Family Unit Subject and Unaccompanied Alien Children Apprehensions Fiscal Year 2016, 18 October 2016, retrieved 7 January 2018, https://www.cbp.gov/ newsroom/stats/southwest-border-unaccompanied-children/fy-2016.

7 United States Customs and Border Protection, CBP Southwest Border Apprehensions/ Inadmissibles, retrieved 7 January 2018, https://www.cbp.gov/sites/default/ files/assets/documents/2017-Dec/CBP\%20Apprehensions.pdf. 
authors have noted that, even though the US has championed the global fight against human trafficking, the emphasis on border security not only undermines the legal protections afforded to human trafficking survivors, but actually contributes to the phenomenon's rise. ${ }^{8}$ For example, James Hathaway highlights that, 'Indeed, because border crossing is itself more challenging and because smugglers are now subject to internationally mandated criminal sanctions if caught [...] the smuggling business will logically become increasingly attractive to organized crime [...] And more tragically still, if those determined to cross cannot afford the higher prices demanded, they will be more vulnerable to exploitation and even to post-crossing enslavement to repay the smuggling debt.'

The fictional case of Carmen, derived from our professional records, exemplifies the experience of abuse common among migrants from the Northern Triangle. Carmen fled domestic violence in Honduras and employed the services of a smuggler, also known as a coyote or guia, to help her travel to the US, where she planned to seek asylum. In Mexico, the smuggling arrangement transformed into an incident of human trafficking. The coyote was affiliated with a criminal network that held Carmen against her will in both Mexico and Texas for months, and forced her and other migrants to perform labour, including sexual services, to repay an alleged debt even though she had already paid the amount the smugglers had initially requested. Carmen was eventually freed by CBP agents and helped the officers in their investigation; however, she was not given any information about her legal rights as a survivor of human trafficking or as an asylum seeker, was not directed to obtain assistance from relevant US agencies or victim service organisations and was instead placed in removal proceedings.

Carmen's story provides a window into how competing and overlapping classifications play out in the US immigration system. Keeping her case in mind, we begin this paper with a review of US legal definitions and immigration protections that are relevant in the wake of the Central American refugee crisis. Next, based on an analysis of our cases and the screening mechanisms used by Law Enforcement Agencies (LEAs) at the US-Mexico border, we examine how the institutions tasked with the preliminary identification and protection of human trafficking survivors frequently fail to do so in practice, thereby

8 Hathaway, pp. 33-34; Chacon, 'Tensions and Trade-Offs', p. 1612.

9 Hathaway, pp. 33-34. 
impeding the survivors' access to legal rights and protections. Finally, we detail how USCIS, the agency responsible for adjudicating certain claims for immigration relief, often misapplies legal standards and conflates human trafficking and human smuggling.

Although this paper is not based on a systematic review of cases, our grassroots observations may prove useful in illustrating several broader trends in the current US anti-trafficking and border apprehension frameworks, and in highlighting the direct effects of conflicting policies and categorisations on trafficking survivors. When survivors are misidentified, they are stripped of their victimhood in the eyes of immigration authorities, LEAs, and the American public, excluding them from remedies and protections, and preventing their stories from being told. This article aims to tell part of those stories.

\section{Legal Protections and Classifications under US Immigration Law}

Survivors of human trafficking are entitled to significant legal protections and aid programmes in the US. The Trafficking Victims Protection Act (TVPA) and its subsequent reauthorisations, including the 2008 William Wilberforce Trafficking Victims Protection Reauthorisation Act (TVPRA), ${ }^{10}$ aim at combating human trafficking domestically and abroad. Its domestic provisions include the protection of survivors against retaliation by traffickers and the expansion of US law enforcement authority to grant certain immigration remedies to victims.

The Department of Homeland Security (DHS), which encompasses CBP, ICE and USCIS, is the primary government agency tasked with the preliminary identification and protection of trafficking survivors. LEAs wield substantial powers in their ability to assist victims, such as by applying for Continued Presence (CP) on their behalf: a temporary immigration status that provides relief from immigration enforcement actions, work authorisation and access to a variety of public benefits. ${ }^{11} \mathrm{ICE}$ formally adjudicates all CP applications,

10 Pub. L. 110-457, 122 Stat. 5044 (2008).

11 USICE, 'Continued Presence: Temporary immigration status for victims of human trafficking', retrieved 22 August 2018, https://www.ice.gov/doclib/humantrafficking/pdf/continued-presence.pdf. 
which, according to the agency, 'should be submitted immediately upon identification of a victim, regardless of whether or not the victim has cooperated'. ${ }^{12}$ DHS may use CP to further extend protections to victims' family members residing in the US or abroad, in order to ensure their safety and to support survivors in their continued collaboration with a law enforcement investigation or prosecution.

Moreover, USCIS has authority to consider cases for more permanent immigration remedies for survivors. The primary legal immigration remedies under the TVPRA are the T visa and the $\mathrm{U}$ visa-two nonimmigrant visas adjudicated by USCIS that provide a path to permanent residency and citizenship in the US. ${ }^{13}$ Significantly faster processing times and the absence of a required LEA certification make the $\mathrm{T}$ visa a more advantageous form of relief than the $\mathrm{U}$ visa for most clients. The focus of this article therefore is on the $\mathrm{T}$ visa.

The statutory protections for human trafficking survivors are codified in the Immigration and Nationality Act (INA) \$101(a)(15)(T) and 214(o). ${ }^{14}$ To qualify for a T-1 nonimmigrant visa, an applicant must show that he/she: (1) is or has been a victim of a severe form of trafficking in persons; (2) is in the US on account of such trafficking; (3) has complied with any reasonable requests for assistance in the investigation or prosecution of trafficking; and (4) would suffer extreme hardship involving unusual and severe harm upon removal from the United States. ${ }^{15}$ The term 'severe form of trafficking in persons' is

12 Ibid.

13 The $\mathrm{U}$ visa is available to victims of certain forms of criminal activity, including domestic violence, human trafficking, sexual assault and other crimes. It requires a certification from a law-enforcement official, prosecutor, judge, or other federal or state authorities that the applicant was a victim of a qualifying criminal activity and has been or is likely to be helpful in an investigation or prosecution. This required certification poses a hurdle to obtaining immigration relief because LEAs are not required to sign these certifications. The $\mathrm{U}$ visa has an annual cap of 10,000 visas and a current backlog of 200,000 applications. The T visa, in comparison, is available only to 'victims of a severe form of trafficking in persons', as defined under US federal law. No law enforcement certification is required, although victims generally must cooperate with law enforcement unless they are minors or have suffered extreme trauma. There is an annual cap of 5,000 visas, which has never been reached.

148 U.S.C. $\$ \$ 1101(\mathrm{a})(15)(\mathrm{T})$ and $1184(\mathrm{o})$.

15 INA $₫ 101(\mathrm{a})(15)(\mathrm{T})(\mathrm{i}) ; 8$ C.F.R. $\$ \int 214.11(\mathrm{~b})(1)-(\mathrm{b})(4)$. 
problematic as it often leads survivors, government actors, and advocates alike to adopt an excessively restrictive understanding of human trafficking. In law, the designation encompasses two broad sub-categories of trafficking: firstly, 'sex trafficking in which a commercial sex act is induced by force, fraud, or coercion, or in which the person induced to perform such act has not attained 18 years of age'; and secondly, 'the recruitment, harboring, transportation, provision, or obtaining of a person for labor or services through the use of force, fraud, or coercion for the purpose of subjection to involuntary servitude, peonage, debt bondage, or slavery'. ${ }^{16}$ The $\mathrm{T}$ visa offers a host of long- and short-term immigration and public benefits, and, unlike asylum, does not involve an adversarial litigation process for individuals in removal proceedings, making it the clear remedy of choice for immigration practitioners presented with several plausible legal claims.

Carmen would certainly meet the legal definition of a 'victim of a severe form of trafficking in persons', in that she was obtained, harboured, and transported for labour or services; endured force and coercion; and her traffickers intended to subject her to involuntary servitude, defined as 'any scheme, plan, or pattern intended to cause a person to believe that, if the person did not enter into or continue in such condition, that person or another person would suffer serious harm or physical restraint; or the abuse or threatened abuse of the legal process' ${ }^{17}$ However, as we will explore further below, ' $[\mathrm{t}]$ he line between voluntary migrants who participate in smuggling schemes and unwilling trafficking victims — a line that is often murky at best - [is] vigilantly policed'. ${ }^{18}$ Our professional experience suggests that, as a result, US immigration authorities and adjudicators at times do not identify individuals like Carmen as survivors of human trafficking solely because they initially entered into a smuggling arrangement voluntarily. ${ }^{19}$

1622 U.S.C. $\$ 7102(9)(\mathrm{A})-(\mathrm{B})$.

1722 U.S.C. $\$ 7102(6)(A)-(B)$.

18 Chacon, 'Tensions and Tradeoffs', p. 1615.

19 The authors base this assertion on formal documents, including Requests for Evidence and Denial Notices, that their clients have received from US Citizenship and Immigration Services on T visa applications. Such documents have asked clients to clarify why they should be granted protection after 'assuming the risk' of consenting to a smuggling arrangement. For a more detailed discussion, see section 'Obtaining Immigration Relief for Human Trafficking Survivors' below. 
Carmen and similar cases may be eligible for $\mathrm{CP}$ at the moment they are identified by LEAs during border apprehension, as well as multiple forms of permanent immigration relief such as asylum and the $\mathrm{T}$ visa, the latter being much more advantageous in the current political and legal immigration context. Although the US continues to uphold international and domestic legal obligations to protect refugees and asylum seekers,${ }^{20}$ several factors have impeded their ability to obtain legal status in the US. These include a drastic backlog in the immigration court system; a lack of access to legal representation, as there is no right to counsel at the government's expense for migrants fighting deportation in the US; and under-funded and under-staffed legal services organisations. ${ }^{21}$ Moreover, Attorney General Sessions' precedential decision on 18 June 2018, in Matter of $A$ - $B$ - overruled a prior decision, Matter of $A$-R$C-G$-, that had explicitly recognised that survivors of domestic violence can meet the refugee definition and qualify for asylum in the US. The decision in $A$ - $B$-also contained language that threatens to foreclose the claims of asylum seekers fleeing violence by other private actors, such as gangs and organised criminals, thereby making asylum for the majority of Central Americans even more untenable. ${ }^{22}$

20 See, e.g., 8 U.S.C. $\$ 1101(\mathrm{a})(42)$.

21 Human Rights First, In the Balance: Backlogs delay protection in the US asylum and immigration court systems, HRF, 2016, p. i ('620,000 removal and asylum cases are pending, and many asylum-seekers are waiting three to six years for resolution of their claims').

22 Matter of A-B-, 27 I\&N Dec. 247 (A.G. 2018) (case referred by US Attorney General Sessions to himself to determine 'whether, and under what circumstances, being a victim of private criminal activity constitutes a cognizable "particular social group" for purposes of an application for asylum or withholding of removal'; C Dickerson, 'Hundreds of Immigrant Children have been Taken from Parents at U.S. Border', The New York Times, 20 April 2018, retrieved 8 June 2018, https://www.nytimes.com/2018/04/20/us/immigrant-childrenseparation-ice.html; Also, see generally, Kids In Need of Defense (KIND), Death By a Thousand Cuts: The Trump administration's systematic assault on the protection of unaccompanied children, KIND, Washington DC, 2018. 
Furthermore, President Donald Trump has used, and continues to use, polarising and sensational language when referring to undocumented migrants in the US, and has received substantial media attention for doing so. ${ }^{23}$ His administration has launched initiatives to restrict both regular and irregular immigration, and to ramp up immigration enforcement, with critics decrying his policies as racially motivated and responsible for the generation of a 'deportation machine'. ${ }^{24}$ The President has initiated various attempts to impose a travel ban on migrants from predominantly Muslim countries, including a ban and/or stricter security protocol for refugees from such countries. ${ }^{25}$ The US government thus offers permanent legal immigration status and public assistance to refugees based on its international obligations while also expressing hostility towards the very same population and expending substantial resources to restrict future refugee acceptance. ${ }^{26}$

Other relevant categories for cases such as Carmen's are 'illegal alien' and 'criminal alien'-legal classifications that are frequently used in public discourse and reinforce society's perception of 'good' and 'bad' migrants. Under the INA, any person who is not a citizen or national of the US is referred to as an

23 In his Presidential Announcement Speech, Donald Trump described Mexican immigrants as: They're bringing drugs. They're bringing crime. They're rapists.' See: 'Full text: Donald Trump announces a presidential bid', The Washington Post, 16 June 2015, retrieved 8 June 2018, https://www.washingtonpost.com/news/ post-politics/wp/2015/06/16/full-text-donald-trump-announces-apresidential-bid/?utm_term=.b6965a8c9711; H Lee and M Ye, 'Donald Trump's False Comments Connecting Mexican Immigrants and Crime', The Washington Post, 8 July 2015.

24 See, e.g., K Mehrotra, 'Lawyers See Immigration Court as Trump "Deportation Machine", Bloomberg, 4 April 2018, retrieved 18 July 2018, https:// www.bloomberg.com/news/articles/2018-04-04/immigration-court-seen-bylawyers-as-trump-deportation-machine.

25 Executive Order Protecting the United States from Entry of Foreign Terrorists, 27 January 2017, retrieved 20 March 2018, https://www.whitehouse.gov/ presidential-actions/executive-order-protecting-nation-foreign-terrorist-entryunited-states/.

26 USCIS Implementation of Jan. 27 Executive Order, USCIS, retrieved 20 March 2018, https://www.uscis.gov/news/alerts/uscis-implementation-jan-27executive-order. 
'alien'. ${ }^{27}$ 'Illegal alien' and 'criminal alien' are not formally defined in the federal statute, but are frequently used by federal immigration agencies, including USCIS, ICE, and CBP. An 'illegal alien' typically refers to an individual who has entered the US unlawfully or who has overstayed or violated the terms of a visa or temporary immigration status. ${ }^{28}$ Although many human trafficking survivors, like Carmen, may enter the US unlawfully and be initially classified as 'illegal aliens', this does not preclude them from also qualifying for one or multiple forms of immigration relief or legal status. Nevertheless, the use of the term 'illegal alien' has repercussions on the ability of human trafficking survivors to obtain protection, since it evokes images of 'uninvited guests, intruders, trespassers, law breakers' ${ }^{29}$ in the public eye. It 'now also carries undeniable racial overtones and is typically associated with the stereotype of an unskilled Mexican male laborer'. ${ }^{30}$ These public perceptions may influence, whether consciously or not, the behaviour of LEAs, adjudicators, and service agencies responsible for identifying and/or protecting survivors of human trafficking, as discussed further below.

The term 'criminal alien' is routinely used by US immigration agencies in formal documents and policy memoranda to refer to migrants who may be inadmissible or deportable based on criminal conviction or conduct, including repeated immigration violations. ${ }^{31}$ ICE's Criminal Alien Program has been widely criticised for sweeping too broadly, classifying a wide range of vulnerable migrants and non-violent offenders who pose little risk to the general American public as 'criminal aliens'. ${ }^{32}$ Furthermore, immigration offences, making up over half of all federal prosecutions in recent years, have been increasingly criminalised, ${ }^{33}$ thereby reinforcing the stereotype of migrants as 'dangers' to

27 INA $\$ 101(\mathrm{a})(3)$.

28 USCIS Glossary of Terms, 'Legalized Aliens', USCIS, retrieved 20 March 2018, https://www.uscis.gov/tools/glossary/legalized-aliens.

29 Srikantiah, p. 188.

30 Ibid.

31 See: USICE Criminal Alien Program, available at: https://www.ice.gov/criminalalien-program (describing federal initiative 'targeting illegal aliens with criminal records who pose a threat to public safety').

32 See: G Cantor, M Noferi and D E Martinez, Enforcement Overdrive: A comprehensive assessment of ICE's Criminal Alien Program, American Immigration Council, 1 November 2015.

33 Transactional Records Access Clearinghouse Reports, Immigration Now 52 Percent of All Federal Criminal Prosecutions, retrieved 7 January 2018, http://trac.syr.edu/ tracreports/crim/446/. 
US society. As explained by Laila Hlass, 'The past few decades have seen a rapid and staggering convergence of the criminal and immigration regimes, termed "crimmigration." This movement has spawned a mammoth deportation and immigrant incarceration apparatus, with increasingly severe penalties for immigrants who have any contact with law enforcement. ${ }^{34}$

In the next section, we explore how these overlapping categories play out in practice, and how LEAs and immigration adjudicators fail to see many human trafficking survivors as more than 'illegal aliens' or 'criminal aliens' responsible for their own victimisation. The Trump administration's latest measures to forcibly separate children from their family members at the US-Mexico border and criminally prosecute all adults who cross the border illegally will only further exacerbate this complex issue. ${ }^{35}$

\section{Failure to Identify and Protect Human Trafficking Survivors in the US}

LEAs are tasked with implementing the often-opposing mandates of identifying and protecting human trafficking survivors, and of removing 'illegal' and 'criminal aliens'. These conflicting priorities become particularly apparent in cases of migrants who have become victims of human trafficking while being smuggled. Since LEAs like CBP or ICE, and local police forces near the US-Mexico border are often the first agencies to have contact with such individuals, their ability to provide quick and accurate screening can have enormous implications. However, although they present themselves as the frontline defence against human trafficking and publicly pledge to assist survivors, ${ }^{36}$ in practice they are failing woefully in this respect.

34 L Hlass, 'The School to Deportation Pipeline', Georgia State University Law Review, vol. 34, no. 3, 2018, pp. 697-763, p. 705.

35 See, e.g., A Serwer, 'Trumpism, Realized', The Atlantic, 20 June 2018, retrieved 19 July 2018, https://www.theatlantic.com/politics/archive/2018/06/childseparation/563252/; T Kopan, 'New DHS Policy Could Separate Families Caught Crossing the Border Illegally', CNN, 7 May 2018, retrieved 8 June 2018, https:/ /edition.cnn.com/2018/05/07/politics/illegal-immigration-borderprosecutions-families-separated/index.html.

36 US Customs and Border Protection, 'Actions CBP is Taking to Enforce TVPA', retrieved 19 August 2018, https://www.cbp.gov/border-security/humantrafficking. 
We have witnessed this failure first-hand; immigration practitioners in our office and within our networks of local service providers routinely identify individuals as human trafficking survivors for the very first time, although many of them have already been screened by various government agencies and may even have passed through the immigration court system or been ordered expeditiously removed. In cases like that of Carmen, ICE or CBP would often find several survivors during raids of houses where coyotes and/or criminal organisations held them against their will and forced them to work or engage in commercial sex. However, among our clients, none of these victims ever received $\mathrm{CP}$ or any information about their legal right to seek protection under the human trafficking framework. Our clients have reported assisting ICE and CBP in investigations by answering questions for several hours and identifying perpetrators in a photo line-up. Nevertheless, some faced removal proceedings while others were ordered expeditiously removed from the US - a much more limited legal proceeding which provides fewer rights and remedies. Thus, while the LEAs evidently sought to combat the smuggling and trafficking networks at play, they failed either to recognise our clients as human trafficking survivors or to comply with DHS's stated practice of referring them to adequate services and providing information about immigration relief. ${ }^{37}$

A key challenge in identifying human trafficking survivors remains that, although borders are seen as the 'frontlines' of anti-trafficking, agencies tasked with implementing border security and immigration controls are not those best-suited to identify survivors of trafficking - a humanitarian role that often involves complex conceptual challenges even for experts specifically trained in these issues. ${ }^{38}$ It is for similar reasons that individuals who express fear of return to their home countries are referred to USCIS for the Credible Fear Interview (CFI) process, which, although often criticised, has many benefits in theory: an asylum officer specifically trained in this area of law and in dealing with traumatised persons conducts a private interview through an interpreter. ${ }^{39}$

37 Department of Homeland Security, Blue Campaign, Identify a Victim, retrieved 15 August 2018, https://www.dhs.gov/blue-campaign/identify-victim.

${ }^{38}$ M McAdam, 'Who's Who at the Border? A rights-based approach to identifying human trafficking at international borders', Anti-Trafficking Review, issue 2, 2013, p. 36; J Lynch and K Hadjimatheou, 'Challenges and Expectations of Safeguarding and Anti-Trafficking Initiatives at the UK Border', Border Criminologies Blog, 17 July 2017, retrieved 5 June 2018, https://www.law.ox.ac.uk/research-subjectgroups/centre-criminology/centreborder-criminologies/blog/2017/07/ challenges-and.

39 INA $\$ 235(\mathrm{~b})(1)(\mathrm{A}) ; 8$ USC $\$ 1225(\mathrm{~b})(1)(\mathrm{A})(2017)$. 
By contrast, CBP is tasked with 'safeguard[ing] America's borders [and] protecting the public from dangerous people and materials', ${ }^{40}$ while also screening migrants including Unaccompanied Alien Children (UAC) and adults for signs of human trafficking. ${ }^{41}$ This is particularly concerning in the case of UACs, for which CBP uses a two-page questionnaire characterised by the nonprofit Appleseed as inadequate, overly formulaic, and lacking in age-appropriate language. ${ }^{42}$ Moreover, CBP officers at times conduct screening in the presence or close proximity of traffickers, or without interpretation or expertise in assessing trauma-related credibility issues. ${ }^{43}$ The identification and referral of trafficking survivors may benefit from a similar approach to the CFI; i.e. if migrants indicate exploitation, or a fear thereof, CBP officials should refer them to USCIS for an in-depth interview to determine whether it is a case of human trafficking.

An additional challenge in the identification process is that human trafficking survivors often do not self-identify as such or respond to traditional screening questions as expected. ${ }^{44}$ In our experience, they may claim that they were 'unlucky' with their chosen coyote, or that they 'had problems' on the way to the US, but often do not regard themselves as trafficked persons. Significantly, many survivors assume that they do not qualify for legal protection if a coyote or smuggler forces them to work or perform sexual services as payback for the costs of the trip and/or an alleged debt. This belief likely has various complex causes, one of which, based on our interactions with clients, LEA officers, and other practitioners, appears to be the labels and terminology used, including 'severe form of trafficking in persons'. Similarly, when we have brought survivors to the attention of US law enforcement or immigration authorities, like USCIS or ICE, the government actors have frequently failed to recognise the above fact patterns as meeting the relevant legal standards. Our experience

40 US CBP, About CBP, 2016, retrieved 20 March 2018, https://www.cbp.gov/ about.

${ }^{41}$ B Cavendish and M Cortazar, Children at the Border: The screening, protection and repatriation of unaccompanied Mexican minors, Appleseed Network, 2011, retrieved 20 March 2018, http://appleseednetwork.org/wp-content/uploads/2012/05/ Children-At-The-Border1.pdf.

42 Ibid.

43 Ibid., p. 6.

44 Of the recent relevant cases at Ayuda, none of the clients self-identified as a trafficking survivor, despite having been screened by CBP and having had interactions with LEAs. 
suggests that LEAs' screening tools and the officers' trauma-informed assessment skills need improving to ensure identification and protection of trafficking survivors.

\section{Obtaining Immigration Relief for Human Trafficking Survivors}

Whereas LEAs are tasked with the preliminary identification of human trafficking survivors, USCIS is the federal agency that adjudicates certain claims for immigration relief, including applications for $\mathrm{T}$ non-immigrant status. Despite the significant protections granted in human trafficking cases under US federal law, USCIS in practice frequently applies misguided and incorrect legal standards to survivors who voluntarily employed the services of smugglers. When voluntary smuggling arrangements evolve into human trafficking, our own experience and published opinions ${ }^{45}$ confirm the findings of several authors that USCIS regularly conflates smuggling and trafficking, normalises the abuses suffered by migrants during the smuggling process, and blames applicants for their own victimisation. ${ }^{46}$

For example, USCIS recently denied a client's case very similar to Carmen's on the grounds that the applicant was smuggled, not trafficked. ${ }^{47}$ The agency recognised that the person performed domestic services in the form of cooking and cleaning for a cartel, yet argued that she consented to be smuggled and essentially 'assumed the risk' of exploitative situations arising along the journey. USCIS stated that the smugglers did not obtain the applicant's labour through force, fraud, or coercion and found instead that she was 'merely directed' to

45 See, e.g., US Citizenship and Immigration Services, Administrative Appeals Office, Matter of O-F-C-C-, 12 June 2017, retrieved 20 March 2018, https://www.uscis.gov/sites/default/files/err/D12\%20-\%20Application $\% 20$ for $\% 20$ T\%20Nonimmigrant $\% 20$ Status/Decisions_Issued_in_2017 /JUN022017_01D12101.pdf.

46 See, e.g., D Haynes, '(Not) Found Chained to a Bed in a Brothel: Conceptual, legal, and procedural failures to fulfill the promise of the Trafficking Victims Protection Act', Georgetown Immigration Law Journal, vol. 21, 2007, p. 353; Srikantiah, p. 192; A T Gallagher, 2010, p. 277 (noting the complex and timeconsuming process required to successfully determine whether or not a vulnerable migrant is a trafficking victim); Chacon, 'Tensions and Trade-Offs', p. 1612.

47 Decisions issued by USCIS are not made publicly available. These decisions are only sent to the applicant and applicant's attorney. 
cook and clean, discounting the coercive nature of the cartel's threats of death, severe harm, indefinite detention, and forced sex. In another instance, the Administrative Appeals Office (AAO) upheld a denial of a T visa application filed by an individual whose smugglers-turned-traffickers used a threat of physical and psychological coercion to force him to carry bags of unknown contents across the US-Mexico border. In arguing that his labour was not the result of force, fraud, or coercion, the AAO stated that 'the Applicant's own account indicates that the smugglers' abusive actions related directly to the need to avoid detection by law enforcement and to the furtherance of the illegal smuggling operation in which the Applicant had willingly participated'. ${ }^{48}$

In these and other cases, USCIS ignored federal legal precedent that human trafficking can arise during the smuggling process. For example, in U.S. v. SotoHuarto, seven men were sentenced on human trafficking charges, and the 23year sentence received by one of the defendants was the longest sentence received under the TVPA at that point in time. ${ }^{49}$ The defendants had trafficked women from Guatemala, Honduras, and El Salvador who had agreed to pay USD 5,000 to be smuggled into the US. Upon arrival, however, the women had been confined in 'safe houses', where they had been forced to cook, clean, and do housework without pay. Furthermore, USCIS has noted in its own Officer Training Module that 'migrant smuggling, while often undertaken in dangerous or degrading conditions, involves consent. Trafficking victims, on the other hand, have either never consented, or if they initially consented, that consent has been rendered meaningless by the coercive, deceptive, or abusive action of the traffickers. ${ }^{50}$

48 US Citizenship and Immigration Services, Administrative Appeals Office, Matter of O-F-C-C-, 12 June 2017, https://www.uscis.gov/sites/default/files/err/ D 12\%20-\%20Application \%20 for\%20T\%20Nonimmigrant $\% 20$ Status/ Decisions_Issued_in_2017/JUN022017_01D12101.pdf.

49 Federal Bureau of Investigation, Enforcing Civil Rights: Justice served in the case of the Texas sex slaves, FBI, 13 February 2004, retrieved 20 March 2018, https:// archives.fbi.gov/archives/news/stories/2004/february/slave_021304.

50 USCIS, Refugee, Asylum and International Operations Directorate (RAIO), Officer Training: Detecting possible victims of trafficking training module, 2012, p. 10, retrieved 20 March 2018, https://www.uscis.gov/sites/default/files/ USCIS/ About\%20Us / Directorates\%20and\%20Program\%20Offices / RAIO/ Trafficking $\% 20$ LP $\% 20 \% 28$ RAIO $\% 29$.pdf. 
Some USCIS officers fail to recognise and identify the overlaps between what they regard as distinct categories of trafficking victims, i.e. individuals assumed to have no decision-making abilities of their own, and smuggled migrants, whose agency in leaving their country of origin somehow negates their subsequent exploitation. As Dina Francesca Haynes points out, 'The law seems to discourage allowing the victim to discuss her motivations and desire to improve her life, in favor of the story that bears a single-minded focus on the exploitation. ${ }^{51}$ Similarly, Srikantiah argues:

The difficulty is that smuggling and trafficking are hard to distinguish from one another. The typical undocumented economic migrant is propelled by various forms of atmospheric 'push' factors, ranging from dire economic conditions and political instability to strained family circumstances. The difference between the typical economic migrant and the trafficking victim is that the trafficking victim is influenced not only by these factors, but also by the actions of an individual wrongdoer: the trafficker. ${ }^{52}$

\section{Conclusion}

The labels, classifications, and accompanying legal consequences related to the terms 'victim of trafficking', 'refugee', 'illegal alien', and 'smuggled migrant' have significant implications on how society, practitioners, and US immigration authorities view and deal with migrants, as has been illustrated in the context of the Central American refugee crisis. Many of our clients self-identify primarily as migrants displaced by violence and come to our office to inquire about asylum. Frequently, they view forced labour, including sex, at the hands of smugglers as an unfortunate occurrence during their journey, but do not regard victimisation by smugglers as a significant part of their narrative.

However, Central American migrants seeking legal protection in the US may fit into several categories at once, and the responses of US immigration authorities to these competing classifications vary depending on public rhetoric and political priorities. The negative discourse surrounding 'illegal

\footnotetext{
51 Haynes, p. 353.

52 Srikantiah, p. 192.
} 
immigration' may lead human trafficking survivors to mask the causes of their migration and the way they entered the US. As a consequence, they may not disclose their victimisation at the hands of smugglers. This further diminishes their chances to be identified by either LEAs or service providers as survivors of human trafficking and to be granted T non-immigrant status. Moreover, when survivors do come forward and highlight their exploitation, LEAs and US immigration adjudicators often react with suspicion and doubt, as if an individual's decision to leave their country of origin and make use of a smuggler to escape dire circumstances negates their victimhood.

Due in large part to the US government's heightened focus on border security and the criminalisation of many forms of migration, the plight of human trafficking survivors reflects a much broader problem: the contradictory nature of border control and anti-trafficking policies in the US. The US is idealised as a 'nation of immigrants' and prides itself for its protection of vulnerable and victimised groups. However, the focus on immigration enforcement and border security-currently intensified under the Trump administration-prevents these ideals from being realised in practice. Without a change, violent organised criminals, including smugglers who traffic desperate people in desperate circumstances, will continue to operate with impunity, and their victims will continue to be denied justice, remaining in the shadows at the boundaries of the legal categories that could change, and potentially even save, their lives.

Katherine Soltis is an Immigration Staff Attorney at Ayuda, a non-profit organisation that serves and advocates for low-income immigrants through direct legal, social, and language services, training, and outreach in the Washington, DC metropolitan region. She graduated cum laude from Harvard Law School and summa cum laude from Duke University, where she obtained her Bachelor's Degree in International Comparative Studies and Political Science. She began her legal career in 2015 as an Equal Justice Works Fellow, sponsored by Verizon Wireless and DLA Piper, at Ayuda, during which time she provided direct representation to human trafficking survivors and coordinated outreach and training on issues related to human trafficking. She is a member of the Northern Virginia Human Trafficking Task Force and the Montgomery County Human Trafficking Task Force. Email: katies@ayuda.com.

Rebecca Walters is a Supervising Immigration Attorney at Ayuda, a nonprofit organisation that serves and advocates for low-income immigrants through direct legal, social, and language services, training, and outreach in the Washington, DC metropolitan region. She graduated summa cum laude from 
American University Washington College of Law and obtained her Bachelor's Degree in Foreign Affairs from the University of Virginia. She began her legal career as a Skadden Fellow at Ayuda's Virginia office. She has over eight years of experience representing both child and adult survivors of human trafficking in a variety of immigration matters for survivors facing deportation. She currently serves as a Steering Committee Member for Freedom Network USA, a national alliance of advocates advancing a human rights-based approach to human trafficking. Email: rebecca@ayuda.com. 